І.В. Телевний${ }^{1}$, В.І. Нікітченко ${ }^{1}$, С.І. Клюфас ${ }^{2}$, А.Г. Дмитрієв ${ }^{3}$

${ }^{1}$ Державний науково-дослідний інститут випробувань і сертифікації озброєння

та військової техніки, Чернігів

${ }^{2}$ Товариство з обмеженою відповідальністю “Авікос”, Львів

${ }^{3}$ Харківський національний університет Повітряних Сил ім. I. Кожедуба, Харків

\title{
ОСОБЛИВОСТІ ДОСЛІДЖЕННЯ БОЄПРИПАСІВ 3 ТЕРМОБАРИЧНИМИ ВИБУХОВИМИ РЕЧОВИНАМИ
}

\begin{abstract}
В статті акцентовано увагу на особливості досліджень боєприпасів з термобаричними вибуховими речовинами. Запропоновано порядок проведення досліджень характеристик боєприпасів, групування оцінок на основі специцфіки їх отримання та порядок оцінювання характеристик боєприпасів з термобаричними вибуховими речовинами виходячи з їх фізичних особливостей фактору ураження.
\end{abstract}

Ключові слова: дослідження боєприпасів, оцінка характеристик, уражсаюі фактори, термобаричні вибухові речовини.

\section{Вступ}

Постановка проблеми. Однією з основних характеристик будь-яких боєприпасів, що безпосередньо впливають на бойові характеристики, є тип бойової частини і тип вибухової речовини, яка застосовується в бойовій частині. Характеристики бойової частини і вибухових речовин $є$ взаємозалежними величинами.

Основним призначенням боєприпасів 3 термобаричними вибуховими речовинами $€$ нанесення максимальних збитків за рахунок впливу ударної хвилі зі значним надлишковим тиском у фронті ударної хвилі та високої температури, що утворюється в процесі вибуху.

Проведення достовірної оцінки характеристик (в тому числі і уражаючих факторів) боєприпасів 3 термобаричними вибуховими речовинами є актуальним завданням при проведенні досліджень боєприпасів.

Аналіз останніх досліджень і публікацій. В [1] розглянуті особливості уражаючих факторів боєприпасів в залежності від хімічної компоновки (рецептури) термобаричних вибухових речовин. В [2] проаналізовано особливості функціонування боєприпасів 3 термобаричними вибуховими речовинами та визначено основні уражаючі фактори вищевказаних боєприпасів. Історія розвитку об'ємнодетонуючих та термобаричних боєприпасів подана в [3]. Функціонування обладнання для виміру параметрів фронту ударної хвилі, яке випускається зарубіжними фірмами, розглянуте в [8-9].

Але на теперішній час існують різні підходи до порядку проведення досліджень боєприпасів 3 термобаричними вибуховими речовинами.
Мета статті. В статті запропоновано порядок оцінювання характеристик боєприпасів 3 термобаричними вибуховими речовинами виходячи 3 їх фізичних особливостей фактору ураження.

\section{Виклад основного матеріалу}

3 метою спрощення отримання характеристик боєприпасів з термобаричними вибуховими речовинами ї доцільно розділити на групи в залежності від способу їх отримання, а саме:

- загальні оцінки - це група оцінок щодо застосування сировини, матеріалів і комплектуючих елементів, виконання техніко-економічних вимог, відповідності вимогам щодо стандартизації та уніфікації, відповідності вимогам до ергономіки та технічної естетики, тощо;

- оцінки які можливо отримати в лабораторних умовах - це група оцінок щодо міцності та безпеки речовин та дослідних зразків (кліматичні та механічні оцінки) тощо;

- оцінки які можливо отримати при проведенні натурних експериментів - це група оцінок для отримання яких експерименти доцільно проводити в полігонних умовах з використання реальних дослідних зразків.

Вищевказаний порядок отримання характеристик боєприпасів 3 термобаричними вибуховими речовинами дозволяє спростити та упорядкувати оцінки технічних, експлуатаційних та бойових характеристик боєприпасів та вибухових речовин.

Нижче наведено основні особливості проведення досліджень боєприпасів 3 термобаричними вибуховими речовинами.

Для оцінки загальних характеристик щодо застосування сировини, матеріалів і комплектуючих 
елементів, виконання техніко-економічних вимог, відповідності вимогам щодо стандартизації та уніфікації, відповідності вимогам до ергономіки та технічної естетики тощо доцільно використовувати нормативну базу, яка застосовується для оцінки боєприпасів та бризантних вибухових речовин.

Визначення показника безвідмовної роботи дослідних зразків з термобаричними вибуховими речовинами потребує значної кількості експериментальних даних. Тому для контролю показника ймовірності безвідмовного спрацювання дослідних зразків у заданих умовах експлуатації доцільно застосувати експериментальний метод 3 наступними вихідними даними: ймовірність безвідмовної роботи 0,95 , довірчий інтервал не менше 0,5. Оцінка кількісних показників надійності у процесі дослідження проводиться одноступеневим методом з обмеженою кількістю відмов.

Вищевказаний порядок дозволить мінімізувати кількість дослідних зразків 3 одночасним забезпеченням заданої достовірності отриманих результатів. Статистичні дані показника ймовірності безвідмовного спрацювання дослідних зразків доцільно отримати під час штатної (підконтрольної) експлуатації.

\section{Лабораторні експерименти.}

В лабораторних умовах проводиться підтвердження в основному стійкості боєприпасів 3 термобаричними вибуховими речовинами до зовнішніх кліматичних та механічних чинників [4].

Оцінку стійкості дослідних зразків до дії зниженої та підвищеної температури середовища проводять у спеціальних камерах холоду та тепла. 3 метою отримання коректних результатів експериментів дослідний зразок в залежності від маси термобаричної вибухової речовини доцільно попередньо витримати в камерах деякий час і тільки після цього проводити експеримент 3 відповідною фіксацією параметрів.

При цьому час від моменту виймання дослідних зразків з камери тепла (холоду) до початку проведення експериментів з фіксацією результатів не повинний перебільшувати 30 хвилин.

Особливостями перевірки стійкості дослідних зразків до дії різких змін температури є врахування впливу трьох температурних циклів, що безперервно слідують один за одним. Кожний цикл необхідно проводити в наступній послідовності. Розміщують дослідний зразок у камеру холоду з температурою мінус $50{ }^{\circ} \mathrm{C}$ та витримують при даній температурі 2 години. Потім переміщають дослідний зразок у камеру тепла 3 температурою $50{ }^{\circ} \mathrm{C}$ та витримують при цій температурі на протязі 2 годин. По вичерпанні часу витримки у камері тепла, цикл повторяють. Час переносу дослідного зразка з камери в камеру не повинно перевищувати 5 хвилин. По за- кінченню останнього циклу виймають дослідні зразки з камери тепла і витримують в нормальних умовах протягом 3 годин та перевіряють стан дослідних зразків. Характеристики зовнішніх факторів, на стійкість до яких здійснюється перевірка дослідних зразків $з$ термобаричними вибуховими речовинами наведені в табл. 1.

Таблиця 1

Характеристики зовнішніх факторів впливу

\begin{tabular}{|c|c|c|c|}
\hline Фактор впливу & $\begin{array}{l}\text { Характеристика } \\
\text { фактору впливу }\end{array}$ & Код & $\begin{array}{c}\text { Значення } \\
\text { фактору } \\
\text { впливу }\end{array}$ \\
\hline \multirow{2}{*}{$\begin{array}{l}\text { Механічний удар } \\
\text { поодинокої дії }\end{array}$} & $\begin{array}{l}\text { Пікове ударне } \\
\text { прискорення, м/ } \mathrm{c}^{2}(\mathrm{~g})\end{array}$ & 1211 & $150(15)$ \\
\hline & $\begin{array}{l}\text { Час дії ударного } \\
\text { прискорення, мс }\end{array}$ & 1212 & 15 \\
\hline $\begin{array}{l}\text { Лінійне приско- } \\
\text { рення }\end{array}$ & $\begin{array}{l}\text { Величина приско- } \\
\text { рення, м/ } \mathrm{c}^{2}(\mathrm{~g})\end{array}$ & 1311 & $150(15)$ \\
\hline $\begin{array}{l}\text { Атмосферний } \\
\text { знижений тиск }\end{array}$ & $\begin{array}{l}\text { Робочий тиск, кПа } \\
\text { (мм рт. ст.) }\end{array}$ & 2121 & $46,7(350)$ \\
\hline \multirow{3}{*}{$\begin{array}{l}\text { Підвищена темпе- } \\
\text { ратура середи }\end{array}$} & Робоча, ${ }^{\circ} \mathrm{C}$ & 2211 & 50 \\
\hline & $\begin{array}{l}\text { Робоча короткочас- } \\
\text { на, }{ }^{\circ} \mathrm{C}\end{array}$ & 2211 & 60 \\
\hline & \begin{tabular}{|l|} 
Гранична, ${ }^{\circ} \mathrm{C}$ \\
\end{tabular} & 2213 & 70 \\
\hline \multirow{2}{*}{$\begin{array}{l}\text { Знижена темпера- } \\
\text { тура середи }\end{array}$} & Робоча, ${ }^{\circ} \mathrm{C}$ & 2221 & Мінус 40 \\
\hline & Гранична, ${ }^{\circ} \mathrm{C}$ & 2223 & Мінус 50 \\
\hline $\begin{array}{l}\text { Підвищена воло- } \\
\text { гість повітря }\end{array}$ & $\begin{array}{l}\text { Відносна вологість } \\
\text { при температурі } 35 \\
{ }^{\circ} \mathrm{C}, \%\end{array}$ & 2311 & 100 \\
\hline $\begin{array}{l}\text { Атмосферні опади } \\
\text { (дощ) }\end{array}$ & $\begin{array}{l}\text { Інтенсивність атмо- } \\
\text { сферних опадів, } \\
\text { мм/год }\end{array}$ & 2411 & 40 \\
\hline \multirow{3}{*}{$\begin{array}{l}\text { Атмосферні } \\
\text { конденсовані } \\
\text { опади (роса і } \\
\text { внутрішнє обле- } \\
\text { деніння) }\end{array}$} & $\begin{array}{l}\text { Знижена температу- } \\
\text { ра середи, }{ }^{\circ} \mathrm{C}\end{array}$ & 2220 & Мінус 20 \\
\hline & $\begin{array}{l}\text { Атмосферний } \\
\text { знижений тиск, кПа } \\
\text { (мм рт. ст.) }\end{array}$ & 2120 & $22,67(170)$ \\
\hline & $\begin{array}{l}\text { Відносна вологість } \\
\text { при температурі } 28 \\
{ }^{\circ} \mathrm{C}, \%, \text { не менше }\end{array}$ & 2311 & 93 \\
\hline \multirow{3}{*}{$\begin{array}{l}\text { Динамічний пил } \\
\text { (пісок) }\end{array}$} & $\begin{array}{l}\text { Відносна вологість, } \\
\%\end{array}$ & 2311 & 50 \\
\hline & $\begin{array}{l}\text { Швидкість циркуля- } \\
\text { ції, м/с }\end{array}$ & 2524 & $10-15$ \\
\hline & 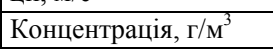 & 2521 & 40 \\
\hline
\end{tabular}

Також дослідні зразки повинні бути стійкими і міцними до дії випадкової широкосмугової вібрації, характеристики якої наведені у табл. 2.

Таблиця 2

Характеристики випадкової широкосмугової вібрації (підйом/спад рівнів - 3дБ/окт)

\begin{tabular}{|c|c|c|}
\hline $\begin{array}{c}\text { Діапазон } \\
\text { частот, } \\
\text { Гц }\end{array}$ & $\begin{array}{c}\text { Сумарне серед- } \\
\text { ньоквадратичне } \\
\text { прискорення, } \\
\mathrm{m} / \mathrm{c}^{2}(\mathrm{~g})\end{array}$ & $\begin{array}{c}\text { Спектральна щіль- } \\
\text { ність, } \mathrm{g}^{2} / \text { Гц }\end{array}$ \\
\hline $10-50$ & $45(4,5)$ & $0,002-0,010$ \\
\hline $50-2000$ & $45(4,5)$ & 0,010 \\
\hline $10-50$ & $32(3,2)$ & 0,020 \\
\hline $50-2000$ & $32(3,2)$ & 0,005 \\
\hline
\end{tabular}

Особливістю перевірки стійкості дослідних зразків до дії атмосферних явищ $є$ проведення рівномірного зрошення водою почергово, або одночасно з чотирьох боків та верхнім струменем під кутом $(40-45)^{\circ}$ з інтенсивністю дощу 50 мм/г на протязі 2 
годин. Після проведення перевірок дослідний зразок повинен бути працездатним.

Під час перевірки стійкості боєприпасів $з$ термобаричними вибуховими речовинами до дії зниженого атмосферного тиску доцільно дослідні зразки витримати в термобарокамерах на протязі 1 години при умові пониженого тиску у камері до 12 кПа (90 мм.рт.ст.). При цьому повинні бути відсутні вм'ятини, сколи, тріщини, а сам зразок бути у працездатному стані. Перевірка стійкості боєприпасів при транспортуванні проводиться в укладальнотранспортувальних ящиках автомобільним транспортом по грунтових дорогах зі швидкістю до 30 км/год на відстань до 500 км та по шосейних дорогах зі швидкістю до 60 км/год на відстань до 5000 км, залізничним та водним транспортом без обмеження швидкості та відстані, авіаційним транспортом до висоти 12000 метрів без обмеження швидкості та відстані.

Оцінка міцності дослідних зразків при транспортуванні може проводитися на приладі імітації транспортування трясінням. При цьому висота падіння повинна бути $(80 \pm 2)$ мм, частота падіння - 60 разів в одну хвилину. Навантаження, що впливають на дослідні зразки при імітації транспортування, не повинні викликати запалювання та детонацію термобаричних вибухових речовин.

Відповідність боєприпасів 3 термобаричними вибуховими речовинами вимогам щодо зберігання проводяться методом прискорених випробувань при дії кліматичних факторів 3 подальшою перевіркою працездатності виробів. Дослідженням підлягають дослідні зразки в пакуванні виробника (в одному або у двох ящиках). Умови проведення випробувань виробів при прискореному методі оцінки збережуваності, які еквівалентні одному року зберігання в умовах закритого приміщення, що не опалюється, наведені в табл. 3.

Таблиця 3

Умови проведення випробувань при прискореному методі

\begin{tabular}{|c|c|c|}
\hline $\begin{array}{c}\text { Вид фактору, } \\
\text { що діє }\end{array}$ & $\begin{array}{c}\text { Характеристика факто- } \\
\text { ру, що діє }\end{array}$ & $\begin{array}{c}\text { Тривалість дії, } \\
\text { годин }\end{array}$ \\
\hline $\begin{array}{c}\text { Понижена тем- } \\
\text { пература }\end{array}$ & $\begin{array}{c}\text { Температура мінус 40 } \\
{ }^{\circ} \mathrm{C}\end{array}$ & 6 \\
\hline $\begin{array}{c}\text { Підвищена } \\
\text { температура }\end{array}$ & $\begin{array}{c}\text { Температура плюс 50 } \\
{ }^{\circ} \mathrm{C}\end{array}$ & 6 \\
\hline
\end{tabular}

Порядок проведення прискорених випробувань може бут наступним:

а) при дії пониженої температури:

- упаковані дослідні зразки поміщують в кліматермокамеру;

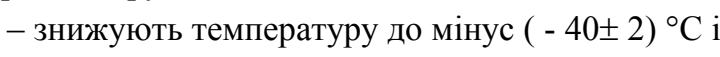
витримують їі протягом часу, наведеного в табл. 3 ;

б) при дії підвищеної температури:
- упаковані дослідні зразки поміщують в кліматермокамеру;

- підвищують температуру до плюс $(50 \pm 2){ }^{\circ} \mathrm{C}$ i витримують їі протягом часу, наведеного в табл. 3.

Після закінчення циклу випробувань, що імітує умови зберігання виробів за 1 рік, упаковані вироби піддають ще дев'яти циклам випробувань у відповідності до табл. 4.

Після закінчення дії кожного з зовнішніх факторів, наведених в табл. 3, перед початком дії наступного зовнішнього фактора необхідно витримати упаковані дослідні зразки не менш ніж дві години в нормальних кліматичних умовах.

Після закінчення прискорених випробувань дослідні зразки виймають 3 пакування і перевіряють на наявність видимих пошкоджень, перевіряють стан лакофарбового покриття і стан маркування та якість функціонування за призначенням.

Натурні експерименти в полігонних умовах.

Перевірка функціонування та практичної дії дослідних зразків з термобаричними вибуховими речовинами $є$ завершальним етапом дослідження характеристик зразків.

Натурні експерименти необхідно організовувати з урахуванням специфіки уражаючої дії термобаричних вибухових речовин [5]. Основними фізичними особливостями є наступні.

При підриві розривного заряду в результаті протікання реакції вибухового перетворення за фронтом детонаційної хвилі утворюються газоподібні продукти, що містять горючі компоненти, які не прореагували, а частки металу термобаричної вибухової речовини прогріваються та починають вступати в реакцію з окисними компонентами продуктів детонації $\left(\mathrm{CO}_{2}, \mathrm{H}_{2} \mathrm{O}\right)$.

Після виходу детонаційної хвилі на поверхню термобаричної вибухової речовини та руйнування корпусу боєприпасів газоподібні продукти починають поширюватися в повітрі, при цьому інтенсивно втрачаючи швидкість. Гарячі металеві частки, володіючи більшою інерцією, обганяють газоподібні продукти і потрапляють у повітря, де інтенсивність ïх горіння суттєво зростає. Енергія, яка при цьому виділяється, йде на підтримку параметрів фронту ударної хвилі і формування протяжної високотемпературної області. Далі за рахунок розвитку турбулентної дифузії відбувається перемішування продуктів детонації з повітрям і догорання горючих компонентів, які не прореагували. Енергія яка при цьому виділяється приводить до збільшення тривалості фази стискання.

Даний фізичний процес вибуху приводить до підвищених параметрів термічного впливу та позитивної фази надлишкового тиску у фронті ударної хвилі в порівнянні з фугасними боєприпасами, спорядженими звичайними вибуховими речовинами. 
Розглянута фізика вибуху боєприпасів з термобаричними вибуховими речовинами безпосередньо впливає і на організацію їх досліджень. Зокрема, на місце установки датчиків тиску у фронті ударної хвилі, датчиків швидкості фронту ударної хвилі, датчиків температури, формування мішеневої обстановки, правильний вибір різних коефіцієнтів (наприклад, впливу поверхні).

Результати уражаючої дії боєприпасів 3 термобаричними вибуховими речовинами на різні цілі необхідно оцінювати виходячи із двох уражаючих факторів вибуху: тиску та температури.

Фактор тиску оцінюється надлишковим тиском $\Delta \mathrm{P}_{\mathrm{m}}$ і питомим імпульсом фази стискання при надлишковому тиску (i+ ) в ударній хвилі [2].

У випадку наявності зони стискання у фронті ударної хвилі характеристики ураження цілей носять квазістатичний характер (миттєва дія постійного тиску), а деформація цілей визначається максимальним надлишковим тиском. При короткій тривалості ударної хвилі реакція цілей на навантаження визначається питомим імпульсом фази стискання (імпульсне навантаження).

Вибір характеру навантаження при оцінці уражаючої дії пов'язаний зі співвідношенням тривалості фази стискання у хвилі $\tau$ і періоду власних коливань об'єкта Т.

Якщо тривалість фази стискання $\tau \leq 0,25 \mathrm{~T}$, то навантаження можна вважати імпульсним, а умова руйнування об'єкту запишеться у вигляді критерію по питомому імпульсу:

$$
i_{+} \geq i_{+}^{\kappa p} .
$$

При $0,25 \leq \tau \leq 10 T$ навантаження стає квазістаціонарним і критерій руйнування виражають через надлишковий тиск:

$$
\Delta P_{m} \geq \Delta P_{m}^{\kappa p} .
$$

Зазначені співвідношення називають частковими критеріями ураження в результаті дії вибухових хвиль боєприпасів 3 термобаричними вибуховими речовинами. При експериментальних дослідженнях боєприпасів велика увага приділяється вимірам надмірного тиску у фронті ударної хвилі і швидкості руху цього фронту, як головних чинників, що визначають ефективність їх застосування [6].

3 рівнянь газової динаміки можна зробити висновок, що швидкість звукової хвилі для ідеального повітряного середовища залежить тільки від температури і розраховується [5-6]:

$$
C=\sqrt{\gamma R T / M}
$$

де $\gamma$ - показник адіабати в нормальних умовах, $\mathrm{R}-$ універсальна газова константа, $T$ - абсолютна температура, $M$ - молярна маса.

В умовах вибуху відбувається стрибок усіх параметрів вказаного рівняння, виникає ударний ім- пульс, наслідками якого є різкий перепад тиску і швидкості переміщення звукової хвилі.

При детонації хімічна реакція поширюється по вибуховій речовині з надзвуковою швидкістю (3-13 км/c), викликаючи газодинамічне розширення 3 різким зростанням температури і ударну хвилю 3 надмірним тиском і надзвуковою швидкістю [11]. Поширення цієї хвилі через повітряне середовище йде 3 надзвуковою швидкістю, але значно меншою, ніж швидкість детонаційної хвилі, різко падаючи за енергетичними властивостями залежно від відстані від точки вибуху. Залежність надмірного тиску у фронті ударної хвилі від відстані до точки вибуху має кубічну залежність і описується емпіричною формулою Садовського [5]:

$$
\Delta p=\frac{0,7 q}{r^{3}}+0,27\left(\frac{0,7 q}{r^{3}}\right)^{2 / 3}+0,084\left(\frac{0,7 q}{r^{3}}\right)^{1 / 3},
$$

де $\Delta p$ - надмірний тиск у фронті ударної хвилі, $\mu P, q$ - маса вибухової речовини, кг (тротиловий еквівалент), г - відстань до точки вибуху, м.

Величини надмірного тиску і швидкості руху фронту пов'язані співвідношенням:

$$
\Delta p=\left(\frac{294,53}{273,15-t}\right)\left(V^{2}-C^{2}\right),
$$

де $t$ - температура зовнішнього повітря, $C, V-$ швидкість руху фронту ударної хвилі, м/с, $C$ - швидкість звуку, м/с.

Швидкість звуку, у свою чергу, зокрема, залежить від температури і вологості довкілля. Залежність швидкості звуку від температури і вологості розраховується за формулою:

$$
C=331,4+0,6 t+0,0124 H,
$$

де $H$ - відносна вологість зовнішнього повітря, \%.

3 урахуванням умов проведення випробувань даною залежністю при проведенні розрахунків можна знехтувати. Таким чином, набір параметрів для вимірювання можна звести до вимірювання швидкості руху фронту ударної хвилі, при цьому провести уточнення місцевої швидкість звуку вимірюванням температури і вологості повітря. Швидкодія датчиків і засобів обробки даних, що поступають 3 них, визначається, виходячи зі швидкоплинності проходження фронту, пікове значення якого знаходиться на його початку, і передбачуваної відстані від датчика до точки вибуху, обраного з урахуванням кубічної залежності (4), виходячи з чутливості датчиків. Оскільки швидкість руху фронту, як правило, лежить в межах більше одного і менше чотирьох чисел М, датчик повинен устигати спрацьовувати приблизно за 700 мкс, а чутливість повинна дозволяти отримувати на обумовленій відстані до точки вибуху на виході максимально прямий передній фронт, оскільки пологий сигнал призводить до великих помилок у вимірах. Необхідно не забувати і 
про те, що, надмірний тиск у фронті ударної хвилі послаблюється в кубічному ступені від відстані згідно (4) і коригувати результати, залежно від відстані між датчиками, якщо вимірювати швидкість по різниці в часі проходження імпульсу між датчиками. Так при перевірці площі суцільного ураження на відкритій місцевості доцільно на відстані 1 м в обидві боки від дослідного зразка розмістити градуйовані лінійки, на відстані 0,5 м та 1 м в різні боки розмістити макети та вимірювальні прилади (на відстані 1 м датчик тиску типу 113В26, або датчик швидкості ударної хвилі типу ЦИС) [8-9]. Дослідні зразки повинні забезпечувати формування уражаючого фактору у вигляді підвищеної температури у центрі підриву не менше $1500^{\circ} \mathrm{C}$. Фактор температури оцінюється розподілом температури від точки підриву до границі області та часу існування області. Для реєстрації результатів необхідно застосовувати високошвидкісні відеокамери та тепловізори. Для перевірки об'єму суцільного ураження у замкнутому приміщені доцільно дослідний зразок розмістити у центрі дерев'яної споруди, ДЗОСу, тощо та додатково при реєстрації результатів необхідно провести оцінку ступеня руйнування споруд $[10 ; 12]$. Розрахунок тиску у фронті ударної хвилі проводиться шляхом зняття показників з вимірювача швидкості або датчика тиску, при використанні вимірювача швидкості, за формулами:

$$
\begin{gathered}
\Delta P_{\phi 1}=1,0078 V_{\phi}^{2}-1,167 \times 10^{5}, \\
\Delta P_{\phi 2}=1,025 \times\left(V_{\phi}^{2}-115797,28\right),
\end{gathered}
$$

де $\Delta P_{\phi}$ - тиск у фронті ударної хвилі, $\Pi a, \mathrm{~V}_{\phi}-$ швидкість фронту ударної хвилі, м/с.

При використанні вимірювача швидкості фронту ударної хвилі $\mathrm{V}_{\phi}$ розрахувати за формулою:

$$
\mathrm{V}_{\phi}=1 / \mathrm{t}
$$

де 1 - відстань між датчиками, м, t - час, що зареєстрований вимірювачем швидкості, с.

Необхідно провести усереднення даних які були отримані за формулами (1) та (2):

$$
\Delta \mathrm{P}_{\phi \text { cep }}=\left(\Delta \mathrm{P}_{\phi 1}+\Delta \mathrm{P}_{\phi 2}\right) / 2,
$$

Розрахунок площі ураження проведемо за формулою:

$$
\mathrm{S}_{\mathrm{y}}=\pi \times \mathrm{R}^{2}
$$

де $\mathrm{S}_{\mathrm{y}}$ - площа ураження, $\mathrm{M}^{2}, \pi=3,14, \mathrm{R}$ - розмір високотемпературної області, м.
Значення показників надлишкового тиску та температури впливають на рівень ураження різних об'єктів, у тому числі особового складу супротивника. На даний момент одержання реальних критеріїв ураження дослідних зразків з термобаричними вибуховими речовинами досить складне через необхідність проведення спеціальних експериментів із залученням медичного забезпечення, тощо. Вищенаведені особливості розглянуті для оцінки основних характеристик боєприпасів 3 термобаричними вибуховими речовинами для зразків масою до 1000 грамів та масою термобаричних вибухових речовин до 700 грамів. Дослідження інших характеристик вищевказаних боєприпасів доцільно проводити за аналогією 3 дослідженнями боєприпасів 3 бризантними вибуховими речовинами. На теперішній час проблемними питаннями дослідження боєприпасів 3 термобаричними вибуховими речовинами є визначення критичних мас, оцінки граничних термінів придатності, ефективності дії зразків на напіввідкритих місцевостях та осколкової дії вищевказаних боєприпасів, тощо.

\section{Висновки}

3 метою мінімізації кількість дослідних зразків 3 одночасним забезпеченням заданої достовірності отриманих результатів при проведенні досліджень боєприпасів з термобаричними вибуховими речовинами доцільно всі характеристики розділити на групи в залежності від порядку їх отримання.

Для підтвердження бойових характеристик полігонний етап (натурні експерименти) досліджень боєприпасів $з$ термобаричними вибуховими речовинами необхідно проводити на завершальному етапі отримання (підтвердження) характеристик боєприпасів. Отримання достовірних оцінок та характеристик при проведенні досліджень можливо тільки при наявності відповідної спеціальної лабораторної та полігонної баз. Розробка боєприпасів з термобаричними вибуховими речовинами вимагає попередніх (теоретичних та експериментальних) досліджень 3 урахуванням поставлених перед конкретними боєприпасами завдань. Розробка методик різних видів досліджень повинна проводитися 3 урахуванням особливостей боєприпасів з термобаричними вибуховими речовинами.

\section{Список літератури}

1. Lemi T. Thermobaric and enhanced blast explosives [Electronic resource] / T. Lemi // Defence Technology. - 2016. № 12(6). - P. 423-445. - Available at: https://www.sciencedirect.com/science/article/pii/S2214914716300927.

2. Особливості функціонування та розробки термобаричних боєприпасів / В.В. Брайко, О.І. Сподін, В.Г. Скляр, І.В. Телевний, Ю.О. Камак, В.І. Нікітченко // Збірник наукових праць Державного науково-дослідного інституту випробувань і сертифікації озброєння та військової техніки. - 2020. - № 2. - С. 37-46. 
3. Аналіз розвитку та основні тенденції застосування термобаричних боєприпасів / В.В. Ларіонов, К.М. Хом'як, Р.В. Казмірчук, О.С. Івахів, М.О. Платонов, О.М. Стаднічук // Збірник наукових праць Національної академії Сухопутних військ ім. гетьмана П. Сагайдачного. - 2016. - № 15. - С. 28-31.

4. Головин Г. Пиросправка. Справочник по взрывчатым веществам, порохам и пиротехническим составам [Елекронний ресурс] / Г. Головин. - М.: 2012. - 310 с. - Режим доступу: https://docplayer.ru/25882729-Pirospravkaspravochnik-po-vzryvchatym-veshchestvam-poroham-i-pirotehnicheskim-sostavam.html.

5. Белопухов Л.П. Ударные волны и детонация / Л.П. Белопухов. - М.: Квант, 2008. - 247 с.

6. Асланов С.К. К теории взрывных волн / С.К. Асланов // Физика горения и взрыва. - 2006. - № 4(42). - С. 93-99.

7. Офіціальний сайт BUSINESSINSIDER.COM. There Are The Weapons That Russian Is Pouring Into Eastern Ukraine.

- Режим доступу: https://www.businessinsider.com/weapons-russia-is-pouring-into-east-ukraine-2015-1?r=UK.

8. Patrick L.W. Air Blast and the Science of Dynamic Pressure Measurements [Electronic resource] / L.W. Patrick. - PCB Piezotronics. - 2016. - Available at: https://www.pcb.com/contentstore/MktgContent/LinkedDocuments/Technotes/TN-310714 Air Blast Lowres.pdf.

9. Офіціальний сайт KISTLER.COM. Blast Pressure Measurements. - Режим доступу: https://www.kistler.com/?type $=669 \&$ fid $=352 \&$ model=download.

10. Бабкин А.В. Средства поражения и боеприпасы / А.В. Бабкин, В.А. Велданов, В.Ф. Грязнов. - М.: МГТУ им. Н.Э. Баумана, 2008. - 984 с.

11. Аркашев А. Зажигательное и огнеметное оружие / А. Аркашев. - М.: Яуза, 2009. - 704 с.

12. Никулин Е.Н. / Средства ближнего боя. Ручные гранатометы // Е.Н. Никулин, Е.Н. Руссков, И.А. Семенов. Санкт Петербург: СтудМед, 2007, - 139 с.

\section{References}

1. Lemi, T. (2016), Thermobaric and enhanced blast explosives, Defence Technology, No. 2(6), pp. 423-445, available at: www.sciencedirect.com/science/article/pii/S2214914716300927.

2. Braiko, V.V., Spodin, O.I., Skliar, V.H., Televnyi, I.V., Kamak, Yu.O. and Nikitchenko, V.I. (2020), "Osoblyvosti funktsionuvannia ta rozrobky termobarychnykh boieprypasiv" [Features of operation and distribution of thermobaric munitions], Collection of Scientific Works of the State Research Institute of Testing and Certification of Weapons and Military Equipment, No. 2, pp. 37-46.

3. Larionov, V.V., Khom'iak, K.M., Kazmirchuk, R.V., Ivakhiv, O.S., Platonov, M.O. and Stadnichuk, O.M. (2016), "Analiz rozvytku ta osnovni tendentsii zastosuvannia termobarychnykh boieprypasiv" [Developmental analysis and main trends of thermobaric ammunition application], Proceedings of the National Academy of Land Forces of Hetman P. Sahaidachny, No. 15 , pp. 28-31.

4. Golovin, G. (2012), "Pyrospravka. Spravochnyk po vzryvchatym veshchestvam, porokham y pyrotekhnycheskym sostavam" [Pirospredelka. Explosives, Gunpowder and Pyrotechnic Compendium Handbook], Moscow, 310 p., available at: www.docplayer.ru/25882729-Pirospravka-spravochnik-po-vzryvchatym-veshchestvam-poroham-i-pirotehnicheskimsostavam.html.

5. Belopukhov, L.P. (2008), “Udarnye volny y detonatsyia” [Shock waves and detonation], Kvant, Moscow, 247 p.

6. Aslanov, C.K. (2006), "K teoryy vzryvnykh voln" [To the theory of blast waves], Physics of Combustion and Explosion, No. 4(42), pp. 93-99.

7. The official site of BUSINESSINSIDER.COM. (2015), There Are The Weapons That Russian Is Pouring Into Eastern Ukraine, available at: www.businessinsider.com/weapons-russia-is-pouring-into-east-ukraine-2015-1?r=UK.

8. Patrick, L.W. (2016), Air Blast and the Science of Dynamic Pressure Measurements, PCB Piezotronics, available at: www.pcb.com/contentstore/MktgContent/LinkedDocuments/Technotes/TN-31-0714_Air_Blast_Lowres.pdf.

9. The official site of KISTLER.COM. (2017), Blast Pressure Measurements, available at: www.kistler.com/?type $=669 \&$ fid $=352 \&$ model $=$ download.

10. Babkyn, A.V., Veldanov, V.A. and Hriaznov, V. (2008), "Sredstva porazhenyia y boeprypasy" [Means of destruction and ammunition], MHTU im. N.E. Baumana, Moscow, 984 p.

11. Arkashev, A. (2009), "Zazhyhatelnoe y ohnemetnoe oruzhye" [Incendiary and flamethrower weapons], Yauza, Moscow, $704 \mathrm{p}$

12. Nykulyn, E.N., Russkov, E.N. and Semenov, Y.A. (2007), "Sredstva blyzhneho boia. Ruchnye hranatomety" [Melee weapons. Hand grenade launchers], StudMed, Saint Petersburg, 139 p.

Надійшла до редколегії 03.02.2020

Схвалена до друку 10.03.2020

\section{Відомості про авторів:}

\section{Телевний Ігор Володимирович}

заступник начальника Державного науково-дослідного інституту випробувань і сертифікації озброєння та військової техніки з випробувань, Чернігів, Україна

https://orcid.org/0000-0003-0761-3013

\section{Information about the authors:}

\section{Igor Televniy}

Deputy Chief of State Scientific Research Institute of Armament and Military Equipment Testing and Certification (on Research), Chernihiv, Ukraine https://orcid.org/0000-0003-0761-3013 
Нікітченко Віктор Іванович

кандидат технічних наук

начальник науково-дослідного відділу

Державного науково-дослідного інституту випробувань

і сертифікації озброєння та військової техніки,

Чернігів, Україна

https://orcid.org/0000-0001-8973-8711

Клюфас Степан Іванович

директор товариства з обмеженою відповідальністю

“Авікос”“, Львів, Україна

https://orcid.org/0000-0002-9239-2755

\section{Дмитрісв Андрій Геннадійович}

кандидат технічних наук

старший науковий співробітник

начальник науково-дослідного відділу

Харківського національного університету

Повітряних Сил ім. І. Кожедуба,

Харків, Україна

https://orcid.org/0000-0002-8710-5598

\section{Viktor Nikitcnenko}

Candidate of Technical Sciences

Chief of the Scientific Research Department

of State Scientific Research Institute of Armament and Military Equipment Testing and Certification, Chernihiv, Ukraine

https://orcid.org/0000-0001-8973-8711

Stepan Klyufas

Director of "Avikos" Ltd.

Lviv, Ukraine

https://orcid.org/0000-0002-9239-2755

\section{Andrii Dmytriiev}

Candidate of Technical Sciences

Senior Research

Head of the Scientific Research Department

of Ivan Kozhedub Kharkiv

National Air Force University,

Kharkiv, Ukraine

https://orcid.org/0000-0002-8710-5598

\section{ОСОБЕННОСТИ ИССЛЕДОВАНИЯ БОЕПРИПАСОВ С ТЕРМОБАРИЧЕСКИМИ} ВЗРЫВЧАСТЫМИ ВЕЩЕСТВАМИ

И.В. Телевный, В.И. Никитченко, С.И. Клюфас, А.Г. Дмитриев

В статье акцентировано внимание на особенности исследования боеприпасов с термобарическими взрывчатыли веществами. Предложен порядок оченивания характеристик боеприпасов с термобарическими взрывчатыми вещзествами исходя с их физических особенностей поражающих факторов. При исследования характеристик боеприпасов их иелесообразно разделить на несколько групп, в зависимости от способа получения характеристик. При проведении всех оценок целесообразно проводить контроль безотказности срабатывания опытных образцов. Оценку безотказности срабатывания опытных образиов предложено производить экспериментальным методом со следующими входными параметрами: вероятность безотказной работы 0,95 с доверительным интервалом не менее 0,5. Оиенку количественных показателей надежности в прочессе исследований производить одноступенчатым методом с ограниченным количеством отказов. Данный порядок позволит минимизировать количество опытных образцов с одновременным обеспечением заданной достоверности полученных результатов. В лабораторных условиях проводится подтверждение в основном стойкости боеприпасов с термобарическими взрывчатыми веществами к внешнему климатическому и механическому воздействию. Проверка функционирования и практического действия опытных образиов боеприпасов с термобарическими взрывчатыми веществами есть завершающим этапом исследования характеристик. Натурнье эксперименть необходимо организовывать с учетом специфики поражающего действии боеприпасов с термобарическими взрывчатыми веществами. Результаты поражающего действия на разные цели необходимо оценивать исходя с соотношения двух поражающих факторов взрыва термобарических смесей (давления и температуры). Разработка боеприпасов с термобарическими взрьвчатыли веществами требует предварительных теоретических и экспериментальных исследований с учетом поставленных перед конкретным боеприпасом задач. Разработка методик разных видов исследований должна проводится с учетом особенностей боеприпасов с термобарическими взрывчатыми веществами.

Ключевые слова: исследование боеприпасов, оченка характеристик, поражаюшие факторы, термобарические взрывчатые вещества.

\section{FEATURES OF RESEARCH OF LIVE AMMUNITIONS WITH THERMOBARIC EXPLOSIVES}

\section{Televniy, V. Nikitcnenko, S. Klyufas, A. Dmytriiev}

In the article attention is accented on the feature of research of live ammunitions with thermobaric explosives. The methodical going is offered near the estimation of descriptions of live ammunitions with thermobaric explosives coming from their physical features of striking factors. At researches of descriptions of live ammunitions of them it is expedient to divide into a few groups, depending on the method of receipt of descriptions. During realization of all estimations it is expedient to conduct control of faultlessness of wearing-out of pre-production models. The estimation of faultlessness of wearing-out of pre-production models it is suggested to produce an experimental method with next entry parameters: probability of faultless work 0,95 with a confidence interval no less than 0,5. Estimation of quantitative reliability indexes in the process of researches to produce a single-stage method with the limited amount of refuses. This order will allow to minimize the amount of pre-production models with the simultaneous providing of the set authenticity of the got results. In laboratory terms confirmation mainly of firmness of live ammunitions is conducted with thermobaric explosives to external climatic and mechanical influence. Verification of functioning and practical action of preproduction models of live ammunitions with thermobaric explosives is the finishing stage of research of descriptions. Model experiments must be organized taking into account a specific striking action of live ammunitions with thermobaric explosives. Results of the striking operating on different aims it is necessary to estimate coming from correlation of two striking factors of explosion of thermobaric mixtures (pressures and temperatures). Development of live ammunitions with thermobaric explosives requires preliminary theoretical and experimental researches taking into account the tasks put before concrete ammunition. Development of methodologies of different types of researches must conducted taking into account the features of live ammunitions with thermobaric explosives.

Keywords: research of live ammunitions, estimation of descriptions, striking factors, thermobaric explosives. 